\title{
Psychological, covid-19 and co-ass students
}

\author{
Sri P. Utami, ${ }^{*}$ Fadhlurrahman
}

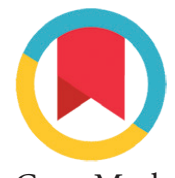

CrossMark

Abstract

Objective: The purpose is To find out the psychological impact of the COVID-19 epidemic on the class 2019 co-ass students of the Faculty of Dentistry Baiturrahmah University.

Material and Methods: This type of research is descriptive research. The target population of this study were c0-ass students of class 2019, with a sample of 142 people. This research was conducted online in the city of Padang using google form media for distributing questionnaires. When the research was carried out in 0ctober 2020. The 7-item General Anxiety Disorders Scale (GAD-7) is the most widely used instrument

for detecting and screening anxiety disorders, and is a module of the Patient Health Questionnaire. Sa total of $52.8 \%$ of respondents disclosed that their family income was unstable and $47.2 \%$ was stable. Results: that there were $5.6 \%$ feeling normal, $36.6 \%$ moderate and $57.7 \%$ severe. In addition, relatives or acquaintances affected by Covid-19 are around $2.8 \%$.

Conclusion: The data analysis method in this study used the SPSS program with univariate and bivariate analysis. Processed data is presented in tabular form and in percentage form.

Keywords: Psychology, Covid- 19 and co- ass students

Cite this Article: Utami SP, Fadhlurrahman. 2021. Psychological, covid-19 and c0-ass students. Journal of Dentomaxillofacial Science 6(2): 98-101. DOI: 10.15562/jdmfs.v6i2.1114

Department of Pediatric, Faculty of Dentistry, Baiturrahmah University, Padang, Indonesia

${ }^{*}$ Correspondence to: Sri P. Utami, Department of Pediatric, Faculty of Dentistry, Baiturrahmah University, Padang, Indonesia panduutamidrg@yahoo.co.id

Received: 190 ctober 2020 Revised: 18 November 2020 Accepted: 4 March 2021 Available Online: 1 August 2021

\section{Introduction}

Coronavirusnew (COVID-2019) has spread rapidly throughout China and several other countries, causing an outbreak of acute infectious pneumonia. According to the OFFI official website of China's National Health Commission, there are 49.824 fraud cases (including 9915 severe cases) and 3434 suspected cases of COVID -19 in China on February 23, 2020. This large-scale contagious public health event is putting enormous pressure on the Chinese government, medical and health care providers, and the general public. Thirty-one provinces in China initiated a Level-1. ${ }^{1}$ public health response The epidemic carries not only the risk of death from viral infection, but also unbearable psychological distress for people in China and around the world. ${ }^{2,3}$ The continuous spread of the epidemic,Strict isolation measures and delays in starting schools, colleges and universities across the country are expected to impact the mental health of class 2019 co-ass Students. There are reports of the psychological impact of the epidemic on the general public, patients, medical staff, children- however, to date there has been no detailed study of the mental health status of class 2019 co-ass students facing the epidemic. Until now, there has been no detailed study on the mental health status of class 2019 co-ass students who are facing an epidemic. Until now there has been no detailed study on the mental health status of class 2019 co-ass students who are facing an epidemic. ${ }^{4}$

Indonesia is one of the countries infected with the corona virus, as informed by the Ministry of
Health of the Republic of Indonesia on its official website (Ministry of Health, 2020) that on May 16th, 2020 around 17.514 corona positive patients, so the development of confirmed corona cases has increased everyday. Meanwhile, in one of the provinces in Indonesia, namely West Sumatra, is the province with the 8th highest positive cases of corona at this time, of which about $95 \%$ are in the city of Padang, which is around 409 people.

The 7-item General Anxiety Disorders Scale (GAD-7) is one of the most widely used instruments for detecting and screening anxiety disorders, and is a module of the Patient Health Questionnaire which is the first self-reported questionnaire developed for primary care, to aid the diagnostic process. specific disorders. ${ }^{5,6}$ GAD-7 takes less than 3 minutes to complete and is easy to score. 10 Currently, GAD-7 is the most widely used measure of anxiety used in clinical and research practice because of its diagnostic reliability and efficiency. It can be applied to the screening, diagnosis and assessment of the severity of anxiety disorders, as well as for social phobia, post-traumatic stress disorder and panic disorder.

Methods of guiding students to regulate their emotions effectively and appropriately during public health emergencies and avoid harm due to crisis events have become a pressing problem for colleges and universities. Therefore, we investigated and analyzed the mental health status of class 2019 co-ass students during the COVID-19 epidemic. 
This study aims to determine the relationship Psychological Impact of the COVID-19 epiodemic on co-ass students of class 2019 at the Faculty of Dentistry, Baiturrahmah University, Padang which was conducted on 142 research samples that have met the inclusion and exclusion criteria.

\section{Material and Methods}

This type of research is descriptive research. The target population of this study were Co-ass students of class 2019, with a sample of 142 people. This research was conducted online in the city of Padang using google form media for distributing questionnaires. When the research was carried out in October 2020.

The research instrument consisted of a structured questionnaire package which, among other things, asked for demographic information, including gender, region, place of residence that diagnosed them, and sources of parents' income. They were also asked about their cognition and preventive behavior regarding COVID-19 and the availability of social support. Additionally, the participants responded to the 7 item Generalized Anxiety Disorder Scale (GAD-7). GAD-7 included seven items based on seven core symptoms and asked respondents for the frequency with which respondents had these symptoms in the past two weeks. Respondents reported their symptoms using a 4-item Likert rating scale ranging from 0 (not all) to 3 (almost daily), such that the total score ranges from 0 to 21 . The GAD-7 is a well-validated screening instrument, procedure; the researcher prepared a questionnaire in the form of a google form; researchers distributed questionnaires via a link to co-ass students of class 2019; after the questionnaire (google form) was distributed, the 2019 batch of Co-ass students filled out the google form; the researcher gave time for co-ass students of class 2019 to fill in the google form; after the google form is filled in, the researcher collects the google form; then the researcher did the data processing; data processing is presented in the form of tables and percentages.

The data analysis method in this study used the SPSS program with univariate and bivariate analysis. Processed data is presented in tabular form and in percentage form.

\section{Results}

Based on the results of the collection and analysis of the data that has been obtained, the authors can conclude that the results of the research table 1 .

From the data above, it can be seen that of the 142 respondents, 8 respondents (5.6\%) had normal feelings, 52 respondents (36.6\%) had moderate feelings and 82 respondents (57.7) had heavy feelings during the covid-19 pandemic table 2.

From the data above,It can be seen that of the 142 respondents in the study, 25 respondents (17.6\%) were male, and 117 respondents (82.4\%) were female.

From the data above,It can be seen that of the 142 respondents in this study, 68 respondents (47.9\%) lived in the city of Padang, 36 respondents (25.4\%) lived outside the city of Padang, and 38 respondents (26.8\%) lived outside West Sumatra table 3.

From the data above, It can be seen that of the 142 respondents in this study, 70 respondents (49.3\%) lived in urban areas, 27 respondents (19.0\%) lived in municipal areas, and 45 respondents (31.7\%) lived in rural areas. So, most respondents live in urban areas (49.3\%) table 4.

Table 1 Distribution of feelings frequency during the pandemic for co-ass students' class of 2019 at Faculty of Dentistry Baiturrahmah University

\begin{tabular}{llcc}
\hline No. & Feelings during a pandemic & Frequency (f) & Percentage (\%) \\
\hline 1 & Normal & 8 & 5.6 \\
2 & Moderate & 52 & 36.6 \\
3 & Weight & 82 & 57.7 \\
& Amount & 142 & 100.0 \\
\hline
\end{tabular}

Table 2 Distribution of Pandemic Sex Frequency Frequency for Class 2019 Co-ass Students at Faculty of Dentistry Baiturrahmah University

\begin{tabular}{llcc}
\hline No. & Gender & Frequency (f) & Percentage (\%) \\
\hline 1. & Male & 25 & 17.6 \\
2. & Women & 117 & 82.4 \\
& Amount & 142 & 100.0 \\
\hline
\end{tabular}


Table 3 Distribution of Regional Frequency During the Pandemic among Co-ass Students Class of 2019 at Faculty of Dentistry Baiturrahmah University

\begin{tabular}{llcc}
\hline No. & $\begin{array}{l}\text { Feelings during a } \\
\text { pandemic }\end{array}$ & Frequency (f) & Percentage (\%) \\
\hline 1. & Padang city & 68 & 47.9 \\
2. & Outside the city of Padang & 36 & 25.4 \\
3. & Outside West Sumatera & 38 & 26.8 \\
& Amount & 142 & 100.0 \\
\hline
\end{tabular}

Table 4 Frequency Distribution of Residence During the Pandemic for Co-ass Students Class of 2019 at Faculty of Dentistry Baiturrahmah University

\begin{tabular}{llcc}
\hline No. & Residence & Frequency (f) & Percentage (\%) \\
\hline 1. & Urban & 70 & 49.3 \\
2. & Municipal city & 27 & 19.0 \\
3. & Rural areas & 45 & 31.7 \\
& Amount & 142 & 100.0 \\
\hline
\end{tabular}

Table 5 Frequency Distribution of Stable Family Income During the Pandemic in Co-ass Students Class of 2019 at Faculty of Dentistry Baiturrahmah University

\begin{tabular}{llcc}
\hline No. & Stable family income & Frequency (f) & Percentage (\%) \\
\hline 1. & Not & 75 & 52.8 \\
2. & Yes & 67 & 47.2 \\
& Amount & 142 & 100.0 \\
\hline
\end{tabular}

From the data above, it can be seen that of the 142 respondents in this study, as many as 75 respondents $(52.8 \%)$ had unstable family income and 67 respondents (47.2\%) respondents had stable family incomes table 5 .

\section{Discussion}

Research conducted by Uswatun. ${ }^{8}$ explains that anxiety affects student learning outcomes, because anxiety tends to produce confusion and perceptual distortion.

Anxiety affects student learning outcomes, because anxiety tends to produce confusion and perceptual distortions. These distortions can interfere with learning by reducing the ability to focus, lowering memory and interfering with the ability to connect one thing to another. The results of the research on 7.143 students showed that $0.9 \%$ of students had severe anxiety, $2.7 \%$ had moderate anxiety and $21.3 \%$ had mild anxiety. ${ }^{9,10}$

The knowledge and attitudes of health students about the prevention of covid-19 in Indonesia in frequency distribution based on sex was found for 25 men (17.6\%) and 117 (82.4\%) women. The distribution of respondents based on gender is more dominated by women with a difference of $64.8 \%$.

Based on the results of the research that has been done, it is obtained the frequency distribution by region. The area where the most respondents lived was in the city of Padang (47.9\%). Furthermore, the results of the study found that most of the respondents live in urban areas (49.3\%).

Based on the results of the study, it is known that since the covid pandemic, $52.8 \%$ of respondents disclosed that their family income was unstable. as much as $47.2 \%$ of respondents stated that their family income is stable. So, it can be concluded that since the covid-19 pandemic, most respondents experienced unstable family income.

Covid-19 is crippling one job after another. An online survey stated that the highest increase in unemployment occurred in urban areas. 55\% of men and $57 \%$ of women who previously worked reported losing their jobs after the pandemic; these events occur in all sectors. The virus has created income insecurity for families across the country.

Although Indonesia has made significant progress in reducing extreme poverty, only 52 million Indonesians can be considered as having safe incomes. In 2019, around 10 percent of Indonesia's population lived in extreme poverty; increases to 13 percent for children and adolescents. However, this percentage covers a considerable gap and various forms of poverty that affect children in Indonesia beyond the household income factor. Nine out of 10 children experience a deficiency in at least one aspect of child welfare, such as access to food and nutrition, health, education, housing, water and sanitation, and child protection. More than half of Indonesia's child population experiences at least two deficiencies outside the financial aspect.

Furthermore, from the results of the research that has been conducted, it was found that the frequency of respondents who live with their parents is the highest category (31.7\%).

The function of the family in the isolation period of COVID-19 is important in the defense and protection of family members, in addition to encouraging adjustments to new habits, achieving new identities, and building new connections.

Emotions that arise in a family can affect the pressure that appears on the family ${ }^{11}$ and are related to family resilience in health and psychology. ${ }^{12}$ Family resilience is important during the isolation period of covid-19 in preparing for new habits, because family resilience affects the lives of family members and contribute to the economic, nurturing, education and outreach aspects. In addition, 
family resilience can protect members at risk and serve to prevent the risk of problems in the family.

Based on the research that has been done, it is also known that some respondents met relatives or acquaintances who were affected by covid- 19 (2.8\%). This means that of the 142 respondents studied, few times encountered acquaintances or relatives who were affected by covid- 19 .

Based on the results of the research conducted, it was found that the reasons for daily life (97.2\%) were the most common criteria experienced by respondents.

Based on the results of research that has been done with the output of Test statistics, it is known that Asymp. Sig. has a value $>0.005$. Thus, it can be concluded that $\mathrm{HO}$ is accepted and $\mathrm{Ha}$ is rejected, which means there is no real (significant) difference or influence between gender, region, place of residence, stable family opinion, living with parents, relatives affected by covid and reasons with the psychological impact of the pandemic. covid-19. So, it can be said that the psychological impact of the epiodemic has no effect on the class 2019 co-ass students. $^{13}$

\section{Conclusion}

Based on the results of the research and discussion described above, it can be concluded that: Co-ass Students of Class 2019 at Faculty of Dentistry Baiturrahmah Padang have a heavy level of feeling during the Covid-19 pandemic; the psychological impact of the Covid-19 pandemic on Co-ass Students Class of 2019 at FKG Baiturrahmah Padang is dominated by female respondents; co-ass Students of Batch 2019 at FKG Baiturrahmah Padang during the Covid-19 pandemic mostly resided in the city of Padang and urban areas; the stable impact of family income due to the Covid-19 pandemic on Co-ass students class of 2019 at Faculty of Dentistry Baiturrahmah University; many of the 2019 Class Co-ass students at Faculty of Dentistry Baiturrahmah University still live with their parents during the Covid-19 pandemic; at least 2019 batch of Co-ass students at Faculty of Dentistry Baiturrahmah University who have acquaintances or relatives affected by covid-19; the reasons for everyday life are a consideration for the 2019 Class Co-ass Students at Baiturrahmah Padang FKG during the Covid-19 pandemic; the psychological impact on the class 2019 co-ass students at Faculty of Dentistry Baiturrahmah
University does not have a direct influence on the daily life of the class 2019 co-ass students.

\section{Acknowledgment}

Thank you for the support Department of Pediatric, Faculty of Dentistry, Baiturrahmah University.

\section{Conflict of Interest}

The authors report no conflict of interest.

\section{References}

1. Deng SQ, Peng HJ. Characteristics and public health responses to companies 2019 onavirus disease outbreak in China. J Clin Med 2020;9: 575.

2. Duan L, Zhu G. Psychological intervention for a ff society affected by the COVID-19 outbreak demic. Lancet Psychiatry 2020;7: 300-302.

3. Xiao C. A new approach to consultation on the 2019 novel coronavirus (COVID-19) -Related psychological and mental problems: structured letter therapy. Psychiatric Investig 2020;17: 175-176.

4. Yang Y, Li W, Zhang Q. et al. Mental health services for older adults in China during the COVID-19 outbreak. Lancet Psychiatry 2020;20: 30079-30081.

5. Cao W, Fang Z, Hou G, et al. The psychological impact of the COVID-19 epidemic on college student in china. Psychiatry Res 2020;287: 112934.

6. Toussaint A, Hüsing P, Gumz A, et al. Sensitivity to change and the minimum clinical importance $\mathrm{ff}$ erence of the 7 item disorder questionnaire generalized anxiety (GAD-7). JA ff ect Disord 2020;265: 395-401.

7. Budikayanti A, Larasari A, Malik K, et al. Generalized anxiety disorder screening in epilepsy patients: using the generalized anxiety disorder version Indonesia-7 (GAD7) which is valid and reliable. Int Neurol Res 2019;2019: 5902610

8. Johnson SU, Ulvenes PG, Øktedalen T. General psychometric properties 7-Item scale anxiety disorder (GAD7) in a heterogeneous psychiatric sample. Front Psychol 2019;10: 1713 .

9. Moreno E, Muñoz-Navarro R, Medrano LA, et al. Factorial invariant of the GAD-7 computerized version across different demographic groups and over time in primary care patients. J. A ff ect Disord 2019;252: 114-121.

10. Hasanah U. Psychological Overview of Students in the Learning Process During the Covid-19 Pandemic. J Ment Nurs 2020;8: 299 - 306.

11. Folkman S, Moscowitz JT. Positive affect and the other side of coping. Am Psychol 2000;55: 647-654.

12. Affleck G, Tennen H. Construing benefits from adversity: adaptational significance and dispositional underpinnings. J Pers 1996;64: 899-922.

13. Puspitawati H, Herawati T, Sarma M. Reliability and validity of indicators of family resilience in Indonesia. J Indonesian Population, 2018;13: 1-14.

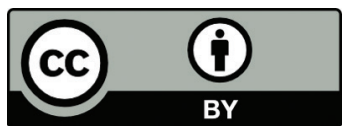

This work is licensed under a Creative Commons Attribution 